Marquette University

e-Publications@Marquette

Theology Faculty Research and Publications

Theology, Department of

$1-1-2009$

\title{
Church, State, and Catholic Ethics: The Kenyan Dilemma
}

Agbonkhianmeghe E. Orobator

Marquette University, agbonkhianmeghe.orobator@marquette.edu

Published version. Theological Studies, Vol. 70, No. 1 (February 2009): 182-185. DOI. (c) 2009

Theological Studies, Inc. Used with permission. 


\title{
CHURCH, STATE, AND CATHOLIC ETHICS: THE KENYAN DILEMMA
}

\author{
Agbonkhianmeghe E. Orobator, S.J.
}

\begin{abstract}
C OMPLEXITY, AMBIGUITY, AND UNCERTAINTY characterize the relationship of church, state, and Catholic ethics in Africa. The East African country of Kenya provides a microcosmic sample of the larger continental profile. The scant literature contains three main lines that indicate an incompatibility of purposes in this relationship. The first recognizes the threefold religious heritage of Africa (indigenous religions, Christianity, and Islam) and the deep affinity between religion and public life in Africa. ${ }^{1}$ "In any African society, there has never been a dichotomy between the secular and the religious or religion and politics." ${ }^{2}$ The second assesses the role of churches in the public sphere. ${ }^{3}$ The third, which defines the focus of
\end{abstract}

Agbonkhianmeghe E. Orobator, S.J., earned his Ph.D. at the University of Leeds and now lectures at Hekima College Jesuit School of Theology in Nairobi; he is also rector of the College's Jesuit community. His special interests include ecclesiology and ethical issues facing the Christian community. His recent publications include two monographs-with Elias O. Opongo, Faith Doing Justice: A Manual for Social Analysis, Catholic Social Teachings, and Social Justice (2007); Theology Brewed in an African Pot (2008) - and several chapters in collections, among which: "Ethics of HIV/AIDS Prevention: Paradigms of a New Discourse from an African Perspective," in Applied Ethics in a World Church: The Padua Conference, ed. Linda Hogan (2008); and "Key Ethical Issues in the Practices and Policies of Refugee Serving NGOs and Churches," in Refugee Rights: Ethics, Advocacy, and Africa, ed. David Hollenbach, S.J. (2008). Orobator will edit a book on the forthcoming synod of African bishops.

1 Two excellent works representative of this strand are Jeff Haynes, Religion and Politics in Africa (Atlantic Highlands, N.J.: Zed, 1996); and Stephen Ellis and Gerrie ter Haar, Worlds of Power: Religious Thought and Political Practice in Africa (New York: Oxford, 2004).

${ }^{2}$ Gideon Gichuhi Githiga, The Church as the Bulwark against Authoritarianism: Development of Church and State Relations in Kenya with Particular Reference to the Years after Political Independence 1963-1992 (Irvine, Calif.: Regnum, 2001) 202. See also Agbonkhianmeghe E. Orobator, Theology Brewed in an African Pot (New York: Orbis, 2008) 1-25.

${ }^{3}$ Paul Gifford, African Christianity: Its Public Role (Bloomington: Indiana University, 1998); Gifford, ed., The Christian Churches and Democratisation of Africa (New York: Brill, 1995); Galia Sabar, Church, State, and Society in Kenya: From Mediation to Opposition, 1963-1993 (London: Frank Cass, 2002). In East Africa, the most authoritative volume remains Holger Bernt Hansen and Michael 
this Note, concerns particular ethical issues related to the sociopolitical contexts of Kenya. Characteristic of this last strand is a somewhat checkered evolution of church-state relationship. The literature identifies three phases of this evolution.

At Kenya's independence the assumed position envisaged the churches cooperating with the state to consolidate the gains of political emancipation. For example, under the regime of founding president Jomo Kenyatta (1963-78), ecclesial bodies like the Kenya Episcopal Conference accepted their cordial role as the conscience of society, a role they fulfilled by issuing pastoral letters and exhortations to public office holders. ${ }^{4}$ When the postcolonial political arrangement degenerated into authoritarianism under the presidency of Daniel arap Moi (1978-2002), cooperation evolved into opposition. ${ }^{5}$ The emphasis shifted to "shaping Kenya's emerging civil society and ... developing an alternative politics." ${ }^{6}$ The opposition was spearheaded by individual church leaders renowned for their strident denunciation of political figures, usually in the form of "political sermons," and proclamation of the virtues and values of Christian social ethics. ${ }^{7}$ The third phase, which extends to the present, surfaced the problem of the contradictory roles played by church leadership concerning matters of governance in society. The present literature sharply criticizes

Twaddle, eds., Religion and Politics in East Africa: The Period since Independence (London: James Currey, 1995). The following articles are useful for understanding the African church's role in the public sphere: Laurenti Magesa, "Has the Church a Role in Politics?" in Leonard Namwera et al., Towards African Christian Liberation (Nairobi: St. Paul Publications-Africa, 1990) 69-85; Magesa,"Sollicitudo Rei Socialis: The Church's Answer to Current Economic Situations," in ibid. 208-17; Joseph Kariuki, "Sollicitudo Rei Socialis: The Answer of the Church to Economic Situations," in ibid. 219-44.

4 For a collection of these letters see Rodrigo Mejia, ed., The Conscience of Society: The Social Teaching of the Catholic Bishops of Kenya, 1960-1995 (Nairobi: Paulines, 1995). See also A. E. Orobator, The Church as Family: African Ecclesiology in Its Social Context (Nairobi: Paulines, 2000) 88-95.

5 David Throup offers an insightful and detailed historical account of the political roles of Protestant and Catholic churches under Moi's regime in "Render unto Caesar the Things that are Caesar's': The Politics of Church-State Conflict in Kenya 1978-1990," in Hansen and Twaddle, Religion and Politics in East Africa 143-46.

6 Sabar, Church, State and Society in Kenya 6.

7 A good example of such publications is Bishop David Gitari, In Season and Out of Season: Sermons to a Nation (Carlisle, UK: Regnum, 1996). The limit of this approach is twofold. First, the ethnic and tribal nature of Kenyan politics renders ecclesial leaders suspect of partisanship. Second, an epistolary intervention is undermined by widespread illiteracy bedeviling Kenya's demographic configuration. In recent years a shift has occurred in favor of a systematic church-sponsored education in civic rights and duties of citizens. See M. Louise Pirouet, "The Churches and Human Rights in Kenya and Uganda since Independence," Religion and Politics in East Africa 247-59. 
the church as part of the problem, rather than as a repository of ethical principles for sociopolitical transformation. This negative perception relates directly to the postelection crisis in Kenya.

In December 2007, the bitterly disputed presidential elections provoked nationwide violence and resurrected atavistic ethnic animosity and unresolved historical injustice. The conflict also posed a serious challenge to Catholic ethics because of the dichotomy established by the warring parties between peaceful resolution and just resolution of the impasse. To plead for peace meant support for the status quo; to call for justice was perceived as supporting the opposition. "Peace" and "Justice" represent central themes of Catholic social teaching; the opposition between them mired church leadership in a political quandary.

Although a substantial monograph assessing the role of the church in Kenya during the postelection crisis has yet to appear, initial indications limn a specter of a divided church with a severely eroded moral capacity "to challenge society and uphold principles of right and wrong, truth and falsity." 9 The church's role in the disputed elections has reinforced a perception of the "coalescence of interests" between church and state, which muffles the church's prophetic voice and provides cover for the state's unethical machinations. ${ }^{10}$

What can be concluded from the foregoing? The political space where the African church engages the state and civil society in view of defining principles and policies for broader action frustrates Catholic ethics in two ways. Besides the amorphous and fragile notion of "state" in Africa, certain elements of African political culture adapt poorly to the principles of Catholic ethics, such as the common good, solidarity, social justice, and a sense of common citizenship. ${ }^{11}$

8 Agbonkhianmeghe E. Orobator, "A Tale of Two Elephants: Overcoming the postelection crisis in Kenya," America 198.8 (March 10, 2008) 14-16.

9 "Church on the Cross," Standard [Kenya], July 8, 2008. This front-page article was one of many scathing attacks on the church in the secular press in the wake of the postelection crisis.

${ }^{10}$ See Simeon O. Ilesanmi, "Religion and Public Life in Africa: A Comparative Perspective on the Ethics of Responsibility," in Taking Responsibility: Comparative Perspectives, ed. Winston Davis (Charlottesville: University of Virginia, 2001) 259-62; Henry Makori, "The Church Can Help Kenya Heal by Speaking the Truth," Catholic Information Service Africa (CISA), http://www.cisanewsafrica. org (accessed August 29, 2008).

11 See editorial, "Africa Awaits a New Dawn," Tablet (June 28, 2008) 2. For a critical study of failed mechanisms of state in Africa, see Patrick Chabal and Jean-Pascal Daloz, Africa Works: Disorder as Political Instrument (Oxford: James Currey, 1999); Jean-François Bayart, Stephen Ellis, and Béatrice Hibou, The Criminalization of the State in Africa (Oxford: James Currey, 1999). 
Kenya's postelection crisis also raised the thorny question of identity that continues to strain traditional Catholic social ethics. In Africa one acquires identity by affiliation with an ethnic group, which guarantees cultural security and facilitates access to public resources. The assumption that "Christian" or "religious" values (e.g., solidarity) can forge a common identity remains unproven. If being Kenyan did not protect many during the postelection crisis, being Christian appears a weaker substitute for a deeply ingrained belief in the protective identity conferred by an exclusionary primary reference group.

In sum: to speculate further on church, state, and Catholic ethics in Kenya would be ineffectual until more studies emerge. ${ }^{12}$ Some recent significant publications draw on principles of Catholic ethics to delineate the parameters of governance, political transformation, and socioeconomic reconstruction while emphasizing justice, human rights, peace building, and democracy. ${ }^{13}$ Yet the responses to the range of questions pertaining to church, state, and Catholic ethics in Africa seem a fraction of what is needed. Positioned halfway between its past role as conscience of society and bulwark against dictatorial regimes and the present perception of its partisanship and lack of credibility, the Kenyan church lacks the ethical credentials of the former and the methodological capacity to shed the latter impression. The debate on church, state, and Catholic ethics in Africa remains a central issue that calls for further research.

12 An excellent collection of short essays dealing with church, state, and Catholic ethics is the recently published JCTR Reader: Church and Politics (Lusaka: Jesuit Centre for Theological Reflection, 2008). Although the articles address the topic from the perspective of the political situation in Zambia, the collection offers interesting parallels with other African countries on a number of issues, including good governance, national identity, social justice, human rights, civic duties, and Catholic social teaching and politics.

13 Aquiline Tarimo and Paulin Manwelo, African Peacemaking and Governance (Nairobi: Acton, 2007); Aquiline Tarimo, Applied Ethics and Africa's Social Reconstruction (Nairobi: Acton, 2005); Elias O. Opongo and Agbonkhianmeghe E. Orobator, Faith Doing Justice: A Manual for Social Analysis, Catholic Social Teachings, and Social Justice (Nairobi: Paulines, 2007); Elias Omondi Opongo, ed., Peace Weavers: Methodologies of Peace Building in Africa (Nairobi: Paulines, 2008). 